\title{
Peningkatan Ekonomi Masyarakat Melalui Kreativitas Pemanfaatan Limbah Minyak Goreng Di Kecamatan Banjarsari
}

\author{
Endah Nawangsasi ${ }^{1)}$, Setyani Sri Haryanti ${ }^{2)}$ Anggoro Panji Nugroho ${ }^{3)}$ \\ STIE AUB Surakarta \\ Email : ${ }^{1)}$ endahnawangsasi32@gmail.com, ${ }^{2}$ setyani_pemnas@ymail.com
}

\begin{abstract}
Abstrak
Pertumbuhan ekonomi industry sangat pesat salah satunya yaitu dampak buruk terhadap lingkungan. Pengelolaan limbah minyak goreng menjadi sabun merupakan salah satu cara membantu menjaga lingkungan yang sehat. Sumber lemak sering kita temui dalam kehidupan sehari-hari adalah minyak yang sering dibuat untuk menggoreng di dapur. Sisa-sisa minyak goreng yang dibuang langsung ke lingkungan tanpa pengolahan terlebih dahulu akan berpengaruh berbahaya bagi lingkungan. Kurangnya edukasi dari masyarakat tentang berbahayanya limbah minyak goreng merupakan salah satu alasan tim pengabdian kepada masyarakat melakukan pengabdian kepada masyarakat terutama kelompok PKK di kecamatan Banjarsari. Tujuan pengabdian ini untuk menginformasikan dan edukasi kelompok ibu-ibu PKK tentang bahaya membuang minyak goreng dan melatih mereka cara membuat sabun dari minyak jelantah sehingga bermanfaat dalam kehidupan sehari-hari.
\end{abstract}

Kata Kunci: Minyak Goreng, Sabun, Kesehatan

\section{PENDAHULUAN}

Persoalan pokok di kota-kota besar. Permasalahan ini telah menumbuhkan kesadaran masyarakat untuk berperan serta ikut andil dalam pengelolaan limbah. Pentingnya kegiatan pembangunan menjadi berkaitan erat dengan pemberdayaan masyarakat dalam memerangi permasalahan limbah dan kebersihan lingkungan. Hal ini akan mendorong masyarakat menjadi lebih aktif dan penuh inisiatif.

Pelantikan ketrampilan pengolahan limbah menjadi nilai tambah merupakan salah satu simulasi kesadaran masyarakat tentang pentingnya pengelolaan dan pendayagunaan limbah. Adanya kegiatan tersebut menambah kesadaran warga yang mengelola limbah minyka goreng. Tujuan wadah pelatihan kegiatan ini adalah untuk membantu pengelola limbah minyak goreng yang ada dan menyadarkan masyarakat akan lingkungan yang sehat, tentram berkaitan dengan kesehatan menu makanan kebutuhan masyarakat sehari-hari. dengan kata lain pengelolaan limbah minyak goreng yang dikatakan seperti sampah dan sekaligus dalam penanganan lingkungan (Munawir,15:33). Penanganan limbah atau bisa dikatakan sampah di masyarakat dapat menjadikan nilai jual yang menguntungkan masyarakat. dengan pengelolaan membentuk kreasi batu melalui program pemberdayaan di masyarakat merupakan suatu bentuk gerakan ekonomi kreatif dan juga nilai lebih, karena menyelamatkan lingkungan hidup.

Dengan program pemerintah yang sudah direncanakan mulai tahun 2016 sebagai tahun ekonomi kreatif Indonesia (Reza, 2016 : 2). Peraturan menteri Negara lingkungan hidup Indonesia no:13 tahum 2012 tentang pedoman pelaksanaan reduce, reuse dan recycle (3R). Dengan berupaya cerdas, efisien dan terencana, 3R masih menghadapi kendala besar. Masyarakat kurang sadar akan sampah dan limbah minyak. Pengelolaan limbah harus menjadi perhatian dan momentum awal membina kesadaran kolektif masyarakat yang akhirnya dapat memanfaatkan limbah, yang memiliki nilai jual sehingga penjualan limbah yang berwawasan lingkungan menjadi budaya baru Indonesia (Mita, $2010: 170$ ).

Kecamatan Banjarsari yang mempunyai luas $14,81 \mathrm{~km}^{2}$ dan 13 kelurahan, serta kepadatan penduduk $10.630 \mathrm{jiwa} / \mathrm{km}^{2}$. Meningkatnya pertumbuhan penduduk di kecamatan Banjarsari berdampak terhadap peningkatan limbah minyak goring yang dihasilkan oleh masyarakat pemukiman, usaha restoran, asrama yang dapat meningkatkan pencemaran lingkungan.

Persoalan limbah minyak goring tentunya menjadi tanggung jawab bersama masyarakat maupun pemerintah. Kesadaran masyarakat membuang limbah yang berbahaya dan beracun yang menyebabkan pencemaran lingkungan atau merusak lingkungan dan pemeritnah mengatur teknis untuk pengelolaan 
limbah. Dari situasi tersebut tim pengabdian masyarakat dari STIE AUB Surakarta, tergerak membantu dalam upaya peningkatan wawasan yang berupaya mendukung kepedulian masyarakat terhadap lingkungan serta mengurangi limbah minyak goring. Secara bertahap akan dilaksanakan sosialisasi dan aktivitas, hal tersebut mendukung mewujudkan program pemerintah yaitu Indonesia bebas limbah.

\section{METODE PENGABDIAN}

Kerangka berpikir untuk memecahkan masalah kegiatan ini dapat diperoleh melalui tahapan sebagai berikut :

1. Permasalahan

a. Kemampuan yang terbatas dalam berwawasan praktis masyarakat dalam mengelola limbah minyak goreng.

b. Keterbatasan wawasan dalam memasarkan

c. Keterbatasan pengelolaan menjual produk.

2. Pemecahan Masalah

a. Melengkapi diri dengan prestasi ceramah/penyuluhan dilanjutkan proses workshop tentang pengelolaan dan pembuatan limbah minyak goreng sabun.

b. Mempersiapkan materi pentingnya kesehatan lingkungan dengan mengumpulkan informasi pentingnya menjaga kesehatan lingkungan dalam masyarakat

c. Memberikan pelatihan pembuatan sabun batang dari limbah minyak goreng

d. Memberikan ceramah tentang pengelolaan keuangan berbisnis.

\section{HASIL DAN PEMBAHASAN}

Pengolahan sisa minyak goreng (jelantah) menjadi sabun membantu meningkatkan ekonomi masyarakat melalui ekonomi kreatif. Dengan adanya keikutsertaan masyarakat dalam wadah kelompok UKM yang terdiri dari ibu-ibu PKK, sangat berperan untuk mewujudkan masyarakat yang mandiri dalam segala hal, karena memiliki visi meningkatkan kemampuan dan kemandirian dalam berwirausaha yang membantu kebutuhan ekonomi sehari-hari.

Presentasi tentang menjaga kebersihan lingkungan, mempersiapkan bahan-bahan pembuatan sabun dan mempraktikkannya cara proses pembuatan sabun menggunakan bahan yang disediakan seperti minyak goreng bekas, larutan $\mathrm{NaOH}$, arang aktif dan parfum. Alat yang dibutuhkan untuk membuat sabun adalah wadah, saringan, timbangan, dan tempat meletakkan sabun.

Pada tahap pertama pembuatan sabun, minyak jelantah dimurnikan semalaman dengan arang aktif dan arang, dan arang dan minyak dimurnikan dengan perbandingan rasio $1: 4$.

Saring minyak jelantah murni dan tambahkan $\mathrm{NaOH}$ sampai menjadi sabun wangi. Dengan tambahan minyak parfum, Anda bisa mencetak sabun sesuai keinginan. Sabun dapat digunakan setelah dikeringkan dan diawetkan di bawah sinar matahari dan ular telah mengeluarkan sabun dari cetakan.

Peserta kelompok ibu-ibu PKK memberikan respon positif saat berlangsungnya pelatihan oleh tim pengabdian. Peserta mengharapkan ada pelatihan pada untuk beberapa limbah rumah tangga yang belum dimanfaatkan yang bermanfaat dan memiliki nilai lebih.

\section{SIMPULAN} adalah :

Adapun kesimpulan yang dapat diambil dari tim pengabdian masyarakat dalam kegiatan tersebut

1. Berlangsung pelatihan dan sosialisasi manfaat limbah minyak jelantah, berharap bahwa limbah minyak tidak lagi membahayakan bagi kesehatan manusia melainkan menjadi hal yang berguna terhadap manusia.

2. Pelatihan pemanfaatan limbah minyak jelantah menjadi sabun dapat membantu meningkatkan ekonomi masyarakat dalam kelompok ibu-ibu PKK yang bertujuan meberdayakan masyarakat untuk berkreasi dan lebih mandiri dalam pengelolaan limbah minyak goreng.

3. Pelatihan pemanfaatan limbah minyak jelantah menjadi sabun tersebut bertujuan menambah sumber pemasukan keuangan bagi ibu-ibu kelompok PKK. 


\section{DAFTAR PUSTAKA}

Abduh, I.M.N. and Si, M., 2018. Ilmu Dan Rekayasa Lingkungan (Vol. 1). Sah Media.

Adi, Rukminto Isbandi. (2003). Pemberdayaan, Pembangunan, Masyarakat dan Intervensi Komunitas (Pengantar Pada Pemikiran dan Pendekatan Peraktis). Jakarta :Lembaga Penerbit Fakultas Ekonomi UI

Alwi, Hasan.(2005). Kamus Besar Bahasa Indonesia. Jakarta: Departemen Pendidikan Nasional Balai Pustaka

Statistik, B. P. 2018. Statistik RataRata Konsumsi per Kapita Seminggu Beberapa Macam Bahan Makanan Penting, 2007-2018. Jakarta: Badan Pusat Statistik.

Keputusan Menteri Negara Lingkungan Hidup Nomor 112 Tahun 2003 Tentang Baku Mutu Air Limbah Domestik.

S, Alex. (2012). Sukses Mengelolah Sampah Organik Menjadi Pupuk Organik. Yogyakarta: Pustaka Baru Press 